\title{
Comparison of Geukensia demissa populations in Rhode Island fringe salt marshes with varying nitrogen loads
}

\author{
Marnita M. Chintala*, Cathleen Wigand, Glen Thursby \\ United States Environmental Protection Agency, Office of Research and Development, National Health and Environmental \\ Effects Research Laboratory, Atlantic Ecology Division, 27 Tarzwell Drive, Narragansett, Rhode Island 02882, USA
}

\begin{abstract}
Increased residential development in coastal watersheds has led to increases in anthropogenic nitrogen inputs into estuaries. Sessile bivalves are good candidate organisms to examine nitrogen enrichment effects on consumers because they contribute significantly to material transport from pelagic to benthic systems. We examined condition index (CI), individual dry weight, density, and total biomass in the ribbed mussel Geukensia demissa (Dillwyn), from 10 marsh sites within Narragansett Bay, Rhode Island, subject to varying watershed sub-basin nitrogen loadings. We tested hypotheses that condition and population attributes of $G$. demissa are driven by watershed sub-basin nitrogen load. There was no clear relationship between the mussel CI and nitrogen load. G. demissa density and total biomass did increase significantly with increases in nitrogen load. Responses in individual mussel dry weight might be an indirect effect of increased nitrogen loading due to eutrophication-induced changes in food availability. Increased nitrogen loads could be increasing $G$. demissa food sources, such as Spartina alterniflora detritus, microheterotrophs, particulate organic matter, or phytoplankton, that subsequently translate into higher G. demissa growth and reproduction.
\end{abstract}

KEY WORDS: Bivalve $\cdot$ Nitrogen $\cdot$ Population attributes $\cdot$ Condition index $\cdot$ Indirect effects

\section{INTRODUCTION}

Increases in human activities and residential development in coastal watersheds have resulted in elevated nitrogen inputs to coastal waters. Coastal fringe marshes are an important ecotone between terrestrial and aquatic systems and may therefore play an important role in processing nitrogen inputs (Correll et al. 1992). In Narragansett Bay, Rhode Island, nitrogen inputs into coastal marsh habitats have been linked to residential land use in specific watershed sub-basins (McKinney et al. 2001, Wigand et al. 2001). Additionally, in fringe marshes of Narragansett Bay, anthropogenic nitrogen inputs from watershed sub-basins may alter plant structure by changing plant cover of dominant species, decreasing number of plant belts, and affecting stable nitrogen isotopic signatures of Spartina alterniflora and Geukensia demissa (Dillwyn) (McKinney et al. 2001, Wigand et al. 2001, 2003). These findings suggest that human activities in Narragansett Bay watersheds are influencing nitrogen cycling in fringe salt marshes (Wigand et al. 2001).

Nitrogen enrichment in coastal waters leads to an increase in primary production and particulate organic matter (Valiela et al. 1992, D'Avanzo \& Kremer 1994). Sessile, benthic organisms at the base of the food chain can integrate conditions over a period of time (Warwick et al. 1990), and might adequately reflect nitrogen-induced changes in primary productivity. One such species is Geukensia demissa, which inhabits intertidal zones of salt marshes along the Atlantic Coast of North America (Bertness 1980, Franz 1997) 
and consumes a wide variety of food sources such as microheterotrophs, phytoplankton, microphytobenthos, and cellulosic detritus to meet its nutritional demands (Kreeger \& Newell 2000). Research in Rhode Island has shown that distribution and abundance of individuals, and age and size structure of the population appear to be a complex product of interactions among juvenile settlement, growth, and biological and physical factors that vary across marsh habitats (Bertness \& Grosholz 1985).

The ecological role of this bivalve has been widely documented and it has been described as a keystone species in marshes because of its dominant biomass and high rates of secondary production (Jordan \& Valiela 1982). Because this bivalve has been shown to have isotopic signatures that reflect the isotopic signature of nitrogen source into the marsh, they are thought to be important in nutrient cycling within a marsh (McClelland et al. 1997, McClelland \& Valiela 1998, McKinney et al. 2001). In Waquoit Bay, MA, Geukensia demissa has been shown to feed on particulate organic matter characteristic of that estuary, demonstrating a direct link between watershed and consumers in the adjoining estuary (McClelland et al. 1997). If G. demissa is food-limited, then increased phytoplankton or organic matter due to increased nitrogen inputs could lead to a concurrent increase in mussel growth or biomass.

Condition index (CI) measures have been widely used with many species of bivalve to assess physiological status of these suspension feeders at the base of the food chain. Many studies have used CI as an assay for monitoring pollution or anthropogenic inputs and disease (Crosby \& Gale 1990). In a comparative study of 2 South Carolina estuaries, oysters Crassostrea virginica from an unpolluted habitat showed significantly higher CI values, suggesting that coliform bacteria contamination can produce measurable differences in oyster condition (Scott \& Lawrence 1982).

We examined Geukensia demissa populations in 10 marshes within Narragansett Bay, that have similar hydrology and geomorphology and that are located along a gradient of nitrogen enrichment from their watershed sub-basin. We collected data for individual-level metrics (seasonal $\mathrm{CI}$, size as indicated by length and individual dry weight) and populationlevel metrics (density and total biomass). We tested the following hypotheses: (1) CI of G. demissa decreases as watershed sub-basin nitrogen load increases, (2) individual-level attributes of G. demissa will increase with increasing watershed sub-basin nitrogen load, and (3) population-level attributes of $G$. demissa will increase with increasing watershed subbasin nitrogen load.

\section{MATERIALS AND METHODS}

Site selection and characteristics. Ten semienclosed sub-estuaries in Narragansett Bay, with emergent fringe salt marshes were chosen for this study (Fig. 1, Table 1). Watershed sub-basins associated with each sub-estuary were delineated using geographic information system (GIS) topographic databases as previously described (McKinney et al. 2001, Wigand et al. 2001). Land-use characteristics and nitrogen loads were determined from land cover analyses as in McKinney et al. (2001). Watershed subbasins were delineated and sub-estuary characteristics (cove area, effective width, and area:perimeter ratios) were calculated using 1:24000 scale USGS topographic maps, and processed using the Environmental Systems Research Institute ARC/INFO software package. The data layer for land use was developed from 1995 aerial photography coded to 0.5 acre $\left(2023.5 \mathrm{~m}^{2}\right)$ minimum polygon resolution. Nitrogen loading to Narragansett Bay marshes was estimated with a nitrogen loading model (NLM) developed for Cape Cod, MA

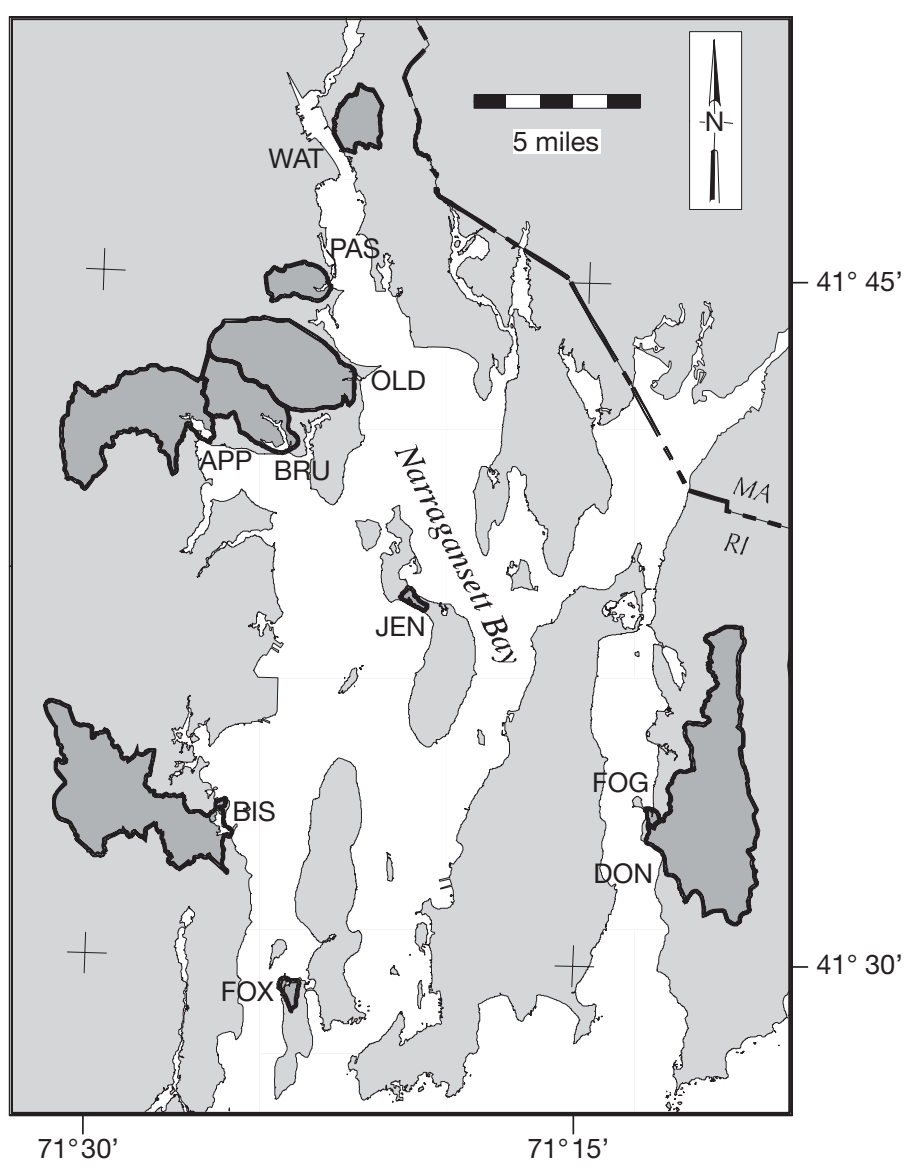

Fig. 1. Locations of the 10 watersheds and marsh sites within Narragansett Bay, Rhode Island, USA. Sites are defined in Table 1.1 mile $=\sim 1.6 \mathrm{~km}$ 


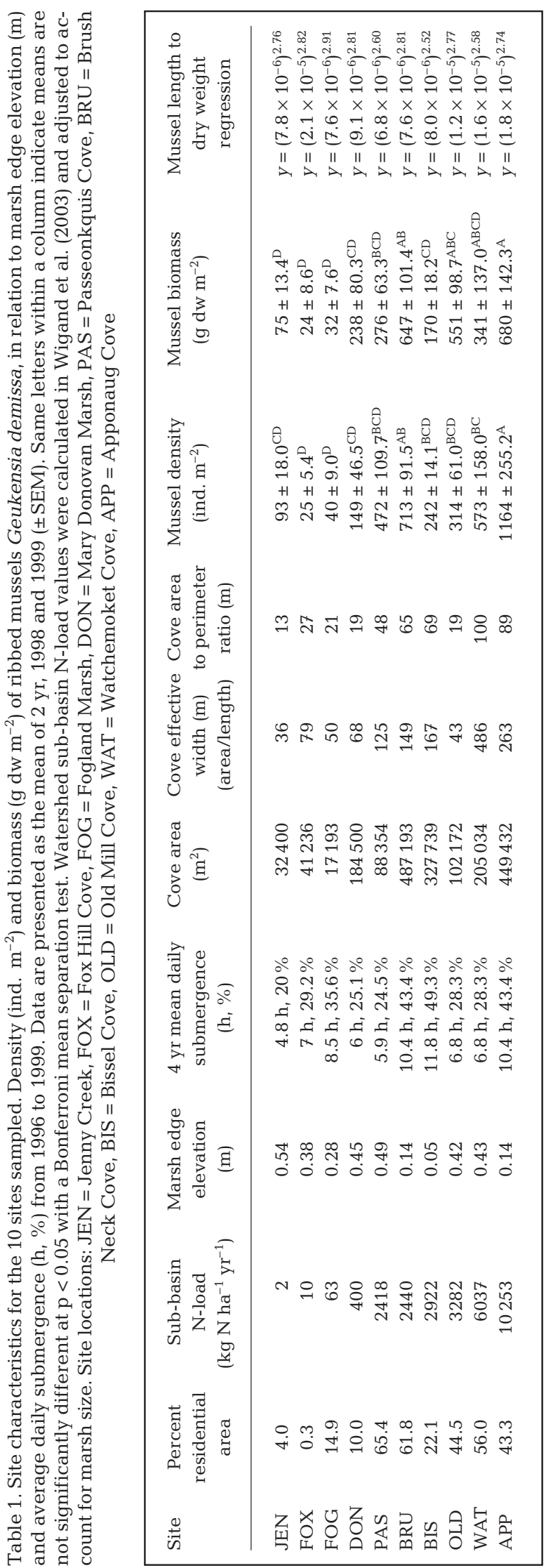

and used in Nantucket, MA and Narragansett Bay (Valiela et al. 1997, 2000; Wigand et al. 2003). The NLM estimates nitrogen loads from atmospheric deposition, fertilizer, and wastewater systems and corrects for nitrogen losses in various compartments (Valiela et al. 1997, 2000).

Average percent residential land use in the watershed sub-basins ranged from 0.3 to $65 \%$ (Table 1). With the exception of Old Mill Cove (OLD), sites with low percent residential area in the watershed $(<20 \%)$ have low area:perimeter ratios, lower effective widths and tend to have smaller sub-estuary areas (Table 1). The OLD site is also different from the other sites in that it has a large, well-developed freshwater input into the estuary. Lowest watershed nitrogen load was at Jenny Creek (JEN) (2 kg N ha $\left.{ }^{-1} \mathrm{yr}^{-1}\right)$, and highest was at Apponaug (APP) (10253 kg N ha'-1 $\mathrm{yr}^{-1}$ ) (Table 1).

Mussel condition. Thirty ribbed mussels were collected in fall 1998 (late August to September), and 20 mussels in winter (late January to early February) 1999, spring (early May) 1999, and summer (late June) 1999 at each of the 10 sites. For each collection date, mussels were haphazardly collected from 5 locations along marsh edge, regardless of mussel size. Distance between collection locations was estimated to be between 4 and $20 \mathrm{~m}$, based on marsh edge length. Mussels were placed in ziploc bags, transported to the lab on ice, and processed within $24 \mathrm{~h}$ of collection. Mussels were cleaned with a brush to remove sediment, excess algae, barnacles and byssus threads. Mussel were dried with a towel, weighed, and were measured with calipers to the nearest $0.1 \mathrm{~mm}$ for length, height and width. Mussels were then shucked, and soft tissues and shells were separately placed into pre-weighed aluminum pans and weighed to the nearest $0.00001 \mathrm{~g}$. Pans were placed in a drying oven at $70^{\circ} \mathrm{C}$ for $48 \mathrm{~h}$ until specimens were completely dried. Dried tissues and shells were weighed to the nearest $0.00001 \mathrm{~g}$. Condition Index (CI) was calculated as follows (Crosby \& Gale 1990):

$$
\mathrm{CI}=\frac{\text { dry soft tissue wt }(\mathrm{g})}{\text { [internal shell cavity capacity }(\mathrm{g})]} \times 1000
$$

Internal shell cavity capacity was calculated by subtracting dry shell weight in air from total weight of mussel in air (shell cleaned and dried) (Crosby \& Gale 1990).

Mussel abundance and biomass. Mussel density and biomass were measured in June 1998, August 1999, and September 1999. All sampling occurred near marsh edge where the densest populations of Geukensia demissa are typically found (Bertness \& Grosholz 1985, Nielsen \& Franz 1995). In 1998, mussels were sampled from triplicate $0.25 \mathrm{~m}^{2}$ quadrats taken $1 \mathrm{~m}$ apart in the low marsh zone (zone dominated by 
Spartina alterniflora). In 1999, for each marsh site, 5 $0.0625 \mathrm{~m}^{2}$ quadrats were sampled at $5 \mathrm{~m}$ intervals along transects with randomly chosen starting points. All living mussels, regardless of size, were counted within quadrats. Quadrat values were converted to abundances $\mathrm{m}^{-2}$ for each marsh location. Ten haphazardly selected mussels from each quadrat were measured for length, height and width to the nearest $0.1 \mathrm{~mm}$ with calipers (for each site, $\mathrm{n}=30$ in 1998 and $\mathrm{n}=50$ in 1999). Individual mussel dry weight was estimated from power regression models of length to dry weight for each location that calculated least squares fit through the points $y=\mathrm{cx}^{\mathrm{b}}\left(\mathrm{r}^{2}\right.$ values ranged from 0.88 to 0.99 ; Table 1 ). Mean number of mussels $\mathrm{m}^{-2}$ and mean individual dry weight per quadrat were multiplied to estimate total biomass $\mathrm{m}^{-2}$.

Additional site data. In August 1998, Spartina alterniflora shoot biomass within three $0.0625 \mathrm{~m}^{2}$ quadrats was determined by clipping aboveground portions of all plants within the quadrat and drying them in an oven at $60^{\circ} \mathrm{C}$ for $48 \mathrm{~h}$. Root biomass was determined by collecting $5 \mathrm{~cm}$ cores within the quadrat, separating root material from sediment, drying roots at $60^{\circ} \mathrm{C}$ for $48 \mathrm{~h}$, and weighing dried roots.

Elevation profiles of the marshes were measured and calculated as described in Thursby \& Abdelrhman (2004) for 2 to 3 transects at each marsh. Submergence was calculated by estimating hourly tidal heights for 1996 to 1999 at each of the sites (Thursby \& Abdelrhman 2004). Flooding time was calculated for mean elevation at marsh edge where mussels were collected. A $4 \mathrm{yr}$ average flooding time was used for correlation analyses with mussel density and biomass. For examining relationships of submergence with seasonal CI measures, number of hours of submergence was calculated for $30 \mathrm{~d}$ prior to collection of mussels for CI measurements. Hydraulic resonance times for each subestuary were calculated as in Biggs et al. (1989), to take into account watershed area, precipitation, discharge volume, and tidal range.

Statistics. Mussel density, biomass, and dry weight were analyzed with a 2-way analysis of variance (ANOVA) and a Bonferroni mean separation technique using SAS (v6). Mussel density, length, biomass, dry weight, and CI were related to watershed sub-basin nitrogen load using Microsoft Excel (v1997) for regression analyses. Relationship of CI with location and season (winter, spring, summer, fall) was analyzed in SAS via 3 methods: (1) a general linear model, (2) analysis of covariance (ANCOVA) with mussel length as a covariate, and (3) ANCOVA with mussel volume as a covariate. ANCOVA was used to account for effects of body size in physiological measures (Packard \& Boardman 1988) and to increase precision (Steel et al. 1997).

\section{RESULTS}

Mussel CI varied significantly with location $\left(F_{9,857}=\right.$ $71.45, \mathrm{p}=0.0001)$ but not season $\left(F_{3,857}=1.57, \mathrm{p}=0.20\right)$ (Fig. 2) when analyzed with a 2-way ANOVA. There was also a significant season $\times$ location interaction $\left(F_{27,857}=9.92, \mathrm{p}=0.0001\right)$. Mean CI values ranged from 63 to 137 (Fig. 2), with lowest values occurring at Watchemoket Cove (WAT) in winter and APP in spring while highest values were in spring at Fogland.

When CI data were analyzed by ANCOVA with mussel length and volume as covariates, both length and volume were significant elements of their models $(p=0.0001)$ indicating that mussels of differing sizes were used. Including length and volume in the analyses $(p=0.3$ and $p=0.6$, respectively) only reduced variance by 10 and $14 \%$, respectively, and produced the same significance levels for 2 elements of the model (location and season $\times$ location) as the 2-way ANOVA analysis. Means, corrected for mussel length and volume, exhibited the same pattern as the uncorrected means. As a result, accounting for length and volume did not appear to impact CI results.

For all seasons there was no significant relationship of CI with nitrogen load. For a majority of sites and seasons, slope of the regression of mussel length to CI was not significantly different from 0 , and produced $\mathrm{r}^{2}$ values ranging from 0 to 0.55 . Highest $\mathrm{r}^{2}$ values were found for OLD in spring (0.55) and APP in spring (0.47). Slopes were often negative indicating a tendency for $\mathrm{CI}$ to decrease with mussel size. When all data were combined, CI showed no significant correlation to changes in edge elevations $(p=0.66)$ or submergence time $30 \mathrm{~d}$ prior to sampling date $(\mathrm{p}=0.65)$.

Mean individual dry weight of mussels varied significantly with season $\left(F_{3,857}=10.8, \mathrm{p}=0.0001\right)$, lo-

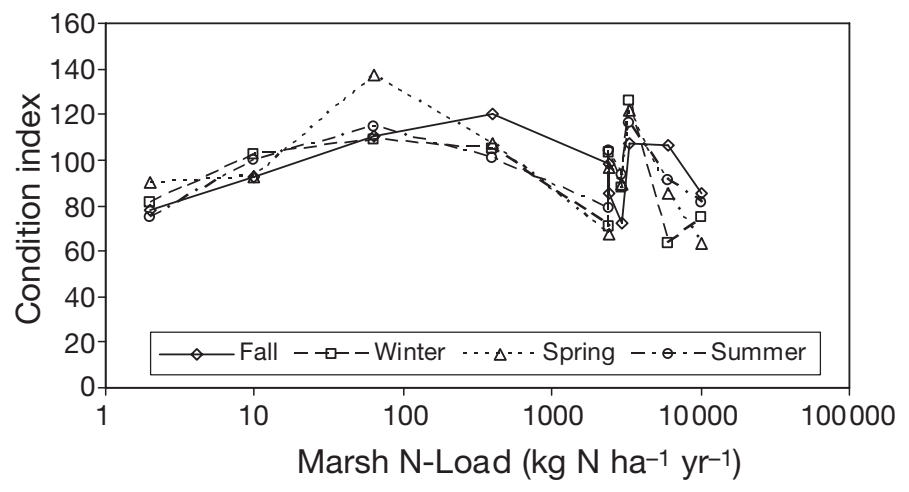

Fig. 2. Relationship between watershed nitrogen load and condition index value for Geukensia demissa for 4 seasons in 1998-1999. For each site $\mathrm{N}=20$ or 30 (fall only). Data represent the least squares means. Error bars are too small to be seen on graph 
cation $\left(F_{9,857}=24.36, \mathrm{p}=0.0001\right)$, and season $\times$ location interaction $\left(F_{27,857}=1.81, \mathrm{p}=0.0075\right)$ (Fig. 3). Mussel dry weights exhibited a pattern along the gradient of watershed sub-basin nitrogen load (Fig. 3) similar to CI values (Fig. 2). Sites with higher mussel dry weights also tended to have higher mussel CI values. Highest mean mussel dry weights occurred at low nitrogen load site, DON, which ranged from $1.12 \mathrm{~g}$ in fall to $2.48 \mathrm{~g}$ in winter. The next highest dry weight values were at a site with a higher nitrogen load, OLD, which had dry weights of 1.38 to $1.96 \mathrm{~g}$. Lowest values were in WAT in fall $(0.22$ g) (Fig. 3). Mean dry body weight tended to be lowest at all sites in fall and was often higher in winter; occasionally dry weights peaked in spring or summer (Fig. 3). There was no significant relationship $(p=0.14)$ between mean mussel length $(\mathrm{mm})$ and watershed sub-basin nitrogen load.

Density of mussels varied significantly with location $\left(F_{9,60}=9.82, \mathrm{p}=0.0001\right)$, but not with year $\left(F_{1,60}=0.54\right.$, $\mathrm{p}=0.79$ ), so data for $2 \mathrm{yr}$ were combined. Highest density of mussels (1164 mussels $\mathrm{m}^{-2}$ ) was found at APP which receives the highest nitrogen load, while lowest density ( 25 mussels $\mathrm{m}^{-2}$ ) was found at the site with lowest percent residential area, FOX (Table 1). Mussel density increased significantly with increasing watershed sub-basin nitrogen load $\left(\mathrm{p}=0.0004, \mathrm{r}^{2}=0.81\right.$; Fig. 4). There was no significant relationship between mussel density and Spartina alterniflora above ground biomass at the sites $(\mathrm{p}=0.53)$.

Mussel biomass patterns with watershed sub-basin nitrogen loading (Fig. 5) were similar to patterns with mussel density (Fig. 4). Total biomass of mussels was significantly different based on location and year $\left(F_{9,60}\right.$ $=2.31, \mathrm{p}=0.03)$. Greatest mussel biomass $(680 \mathrm{~g} \mathrm{dw}$ $\mathrm{m}^{-2}$ ) was found at APP, the site with highest mussel density. Lowest mussel biomass $\left(24 \mathrm{~g} \mathrm{dw} \mathrm{m}^{-2}\right)$ occurred

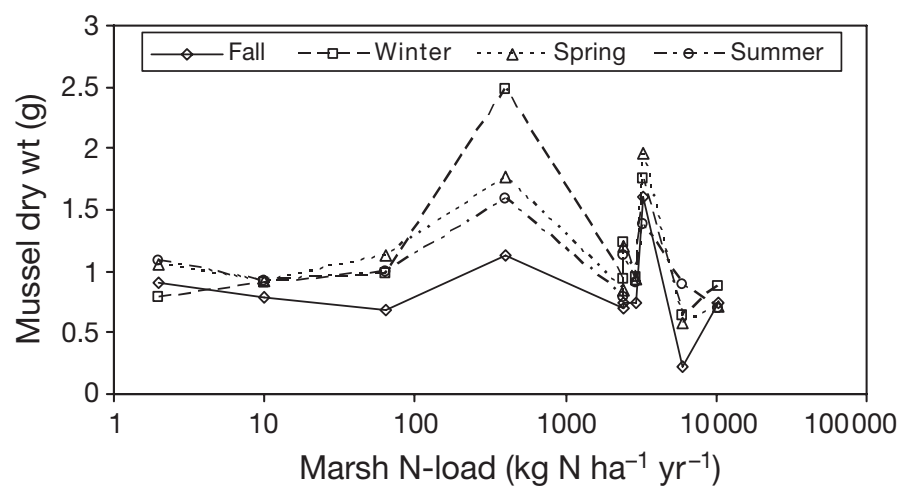

Fig. 3. Relationship between watershed nitrogen load and mean individual dry weight for Geukensia demissa for 4 seasons in 1998-1999. For each site $\mathrm{N}=20$ or 30 (fall only). Error bars are too small to be seen on graph

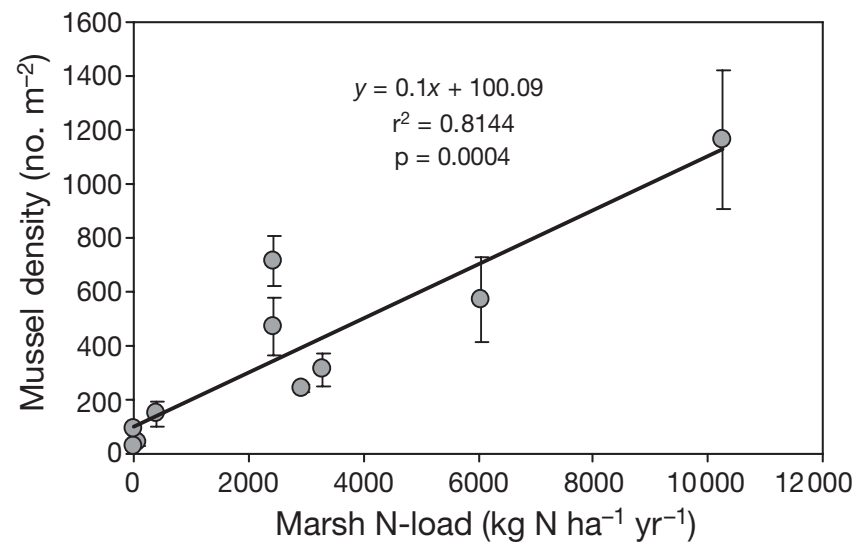

Fig. 4. Relationship between watershed nitrogen load and mean density (ind. $\mathrm{m}^{-2}$ ) of Geukensia demissa at 10 sites in Narragansett Bay from 1998 ( $N=3$ quadrats per site) and 1999 ( $N=5$ quadrats per site) combined. Error bars represent $\mathrm{SE}$ of mean

at FOX, the site with lowest mussel density (Table 1). As watershed sub-basin nitrogen load increased, mussel total biomass increased significantly $\left(p=0.02, r^{2}=\right.$ 0.52; Fig. 5). Sites with lower nitrogen load (FOX, JEN, DON, and FOG) were separated from other sites with a Bonferroni mean separation based on mussel density and biomass.

There was no statistically significant relationship between mussel density and biomass and marsh edge elevation $\left(p=0.21, r^{2}=0.18\right.$, and $p=0.31, r^{2}=0.13$, respectively). The relationship between mussel density and average submergence was not statistically significant $\left(p=0.20, r^{2}=0.20\right)$. There was no relationship between mussel density and biomass and hydraulic resonance time for the sub-estuary $(\mathrm{p}=0.41$ and 0.23 , respectively).

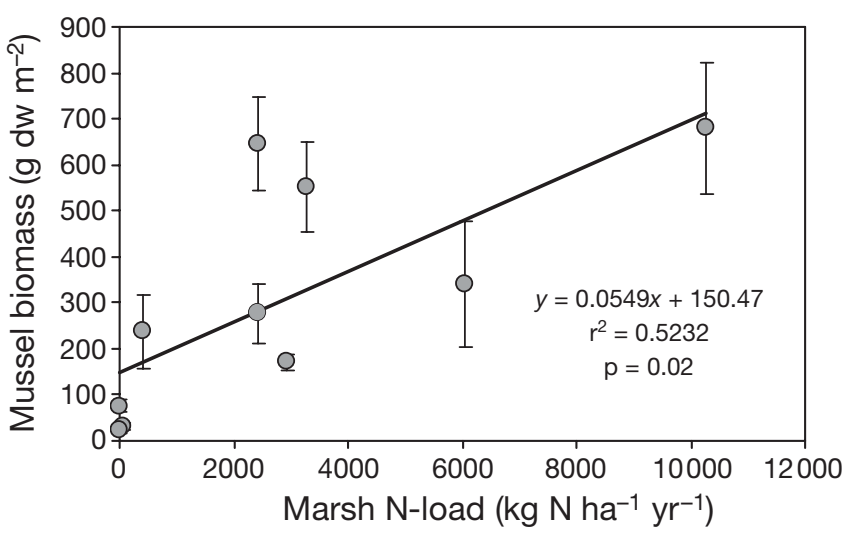

Fig. 5. Relationship between watershed nitrogen load and mean biomass $\left(\mathrm{g} \mathrm{dw} \mathrm{m}^{-2}\right.$ ) of Geukensia demissa at 10 sites in Narragansett Bay from 1998 ( $\mathrm{N}=3$ quadrats per site) and 1999 ( $\mathrm{N}=5$ quadrats per site) combined. Error bars represent $\mathrm{SE}$ of mean 


\section{DISCUSSION}

We examined Geukensia demissa populations in fringe salt marshes of Narragansett Bay along a gradient of increasing watershed sub-basin nitrogen loads. Previous research by McKinney et al. (2001) has shown that the ribbed mussel nitrogen isotopic ratio is altered by human-derived nitrogen from watershed subbasins adjacent to Narragansett Bay salt marshes. However, we found no relationship between mussel physiological status (CI) and location related to nitrogen load from the watershed sub-basin. This result does not mean that nitrogen enrichment from the watershed sub-basin did not affect the physiological function of the mussels. One of the reasons why differences in condition were not detected in this study could be that the mussels in the sites with higher potential nitrogen load values could have been accumulating stored carbohydrate and lipid reserves for gametogenesis due to increased food availability. These storage products are not rich in nitrogen and probably would not be as affected by increased nitrogen load from the watershed sub-basin.

Individual mussel dry weight did not increase with increased watershed sub-basin nitrogen loads as hypothesized. The dry weight of a mussel could be related to rates of food assimilation which are usually complex and determined by a number of factors such as feeding time (in terms of amount of daily submergence), food density, and food quality (Franz 1993, 1997). Mussel density could be a limiting factor to increased dry weight of Geukensia demissa individuals; however, the individual dry weight could be impacted by interactions with unmeasured factors such as food availability or by bias due to sub-sampling procedures.

The density of ribbed mussels found in this study (range of 25 to 1164 mussels $\mathrm{m}^{-2}$ ) was not high compared to other studies which examined mussels of all sizes. The number of mussels found by Evgenidou \& Valiela (2002) at their lowest tidal elevation range in a Massachusetts marsh was $2859 \pm 257$ mussels $\mathrm{m}^{-2}$. Our mussel densities were similar to the densities of the 10 to $20 \mathrm{~cm}$ tidal range in the previous study (range of 251 to 896 mussels $\mathrm{m}^{-2}$ ), and could reflect differences in edge elevation between Massachusetts and Rhode Island. Bertness \& Grosholz (1985) found a higher density of ribbed mussels (mean of $1235 \mathrm{~m}^{-2}$ ) in a different Rhode Island marsh, and Nielsen \& Franz (1995) found a mean density of $9227 \pm 731$ mussels $\mathrm{m}^{-2}$ at the marsh edge in Jamaica Bay, NY. Differential survival could help to influence the density of the mussels at these 10 RI sites, since intraspecific competition often results in death of smaller individuals (Bertness \& Grosholz 1985). Sources of potential mortality were not measured as part of this study.

Mussel density and total biomass significantly increased with the nitrogen load within the watershed sub-basin as hypothesized. The only other study that examined the relationship between Geukensia demissa populations and land-derived nitrogen loading was in 3 Waquoit Bay, MA estuaries with a range of 12 to $601 \mathrm{~kg} \mathrm{~N} \mathrm{~h}^{-1} \mathrm{yr}^{-1}$ (Evgenidou \& Valiela 2002). That study found that eutrophication increased shell growth in smaller mussels, but was not correlated with increased mussel density. They also found that the growth rates (based on shell length) of only the younger ribbed mussels $(<30 \mathrm{~mm})$ increased in response to greater food supply; this result was attributed to a higher concentration of food particles available in estuaries with higher nitrogen loads (Evgenidou \& Valiela 2002). Our study found that mussel density and total biomass increased with increasing nitrogen loads from the watershed subbasin, but growth rates were not measured.

These results are complex and pose a number of potential direct and indirect pathways for the effects of nitrogen loading on Geukensia demissa density and biomass. Nitrogen inputs could be alleviating food limitation in marshes. As an omnivore, G. demissa could be utilizing detritus, benthic microalgae, microheterotrophs, and phytoplankton based on the availability of these potential food sources. As nitrogen inputs increase Spartina alterniflora density and areal extent (Wigand et al. 2003), the amount of S. alterni-

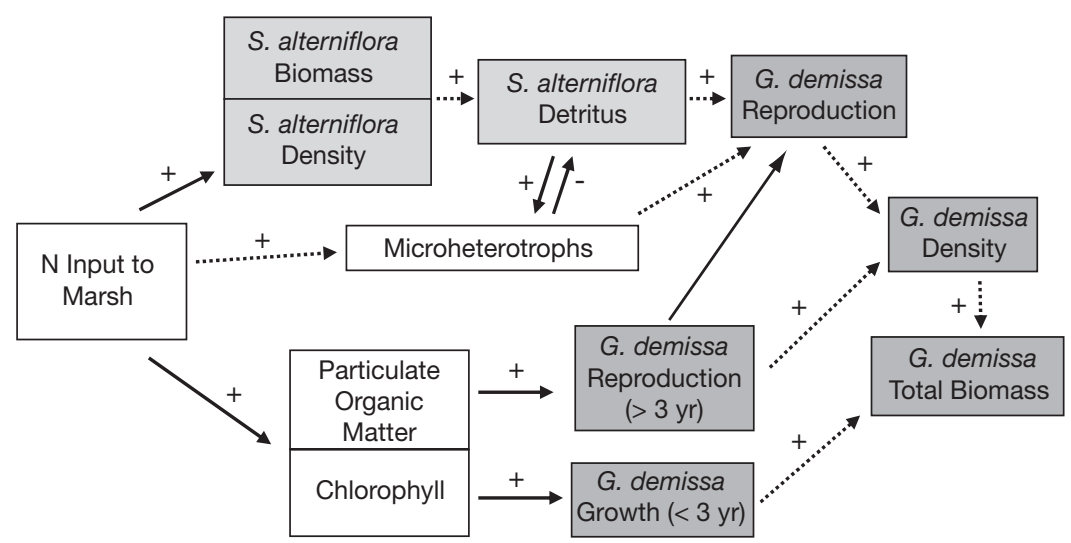

Fig. 6. Diagram of possible direct and indirect pathways for effect of nitrogen loading on Geukensia demissa density and biomass. Dark lines indicate relationships from literature (Evgenidou \& Valiela 2002, Kreeger \& Newell 2000, and Wigand et al. 2003, 2004). Dotted lines indicate hypothesized relationships based on results of this study 
flora detritus available in the marsh should increase. Kreeger et al. (1990) showed that G. demissa in intertidal conditions utilized lignocellulosic carbon from $S$. alterniflora detritus more efficiently than subtidal mussels, and in New England marshes the organic matter produced by $S$. alterniflora makes an important contribution to ribbed mussel growth (Peterson et al. 1986). Mussels may be utilizing $S$. alterniflora detrital material indirectly by consuming detritus-associated microheterotrophs (Kreeger \& Newell 1996). G. demissa has been shown to be able to filter microheterotrophs from detritus and the water column and can assimilate this food source with high efficiency (Kreeger \& Newell 2000). Utilization of these food sources could lead to increased mussel reproduction, followed by higher mussel densities and total biomass (Fig. 6). Evgenidou \& Valiela (2002) found that nitrogen inputs led to increased chlorophyll and particulate organic matter in the water. Phytoplankton could represent an important food resource for this suspension feeder (Kreeger $\&$ Newell 2000) so that subsequent increases in growth and reproduction with increased food supplies may lead to subsequent increases in G. demissa density and biomass over time (Fig. 6).

Bivalves are benthic integrators of the water column, and are thus influenced by estuary inputs as well as land-derived inputs. Watershed sub-basin inputs could be localized, and thus while mussels do ultimately receive part of their nutrient material from watershed sub-basins, the nitrogen loadings were not sufficient to alter their physiological state. Potential food sources were not measured as part of this study so it is unclear if mussel food supplies did indeed vary with watershed sub-basin nitrogen load as has been shown in other studies. Mussel density is probably related to food quality and availability, the physical characteristics of Narragansett Bay, and location of conspecifics. Our results showed that on a gross scale, density and total biomass of mussels increased as nitrogen load in watershed sub-basin increased.

Acknowledgements. We thank D. Stetson, R. McKinney, C. Richmond, G. Cicchetti and J. Lake for field assistance with this project. A. Beck, Dr. R. Green and Dr. K. Raposa assisted with site selection on Prudence Island. Dr. J. Heltshe provided statistical consultation. M. Charpentier determined watershed sub-basin land use and sub-estuary characteristics. Comments of W. Munns, T. Gleason, E. Hinchey, R. McKinney, S. Benyi, and 3 anonymous reviewers greatly improved the manuscript. This is EPA Atlantic Ecology Division contribution number 03-009. Mention of trade names or commercial products does not constitute endorsement or recommendation for use by the U.S. Environmental Protection Agency. Although the research described in this article has been funded by the U.S. Environmental Protection Agency, it has not been subjected to Agency review. Therefore, it does not necessarily reflect the views of the Agency.

\section{LITERATURE CITED}

Bertness MD (1980) Growth and mortality in the ribbed mussel Geukensia demissa (Bivalvia:Mytilidae). Veliger 23:62-69

Bertness MD, Grosholz E (1985) Population dynamics of the ribbed mussel Geukensia demissa: the costs and benefits of aggregated distribution. Oecologia 67:192-204

Biggs RB, DeMoss TB, Carter MM, Beasley EL (1989) Susceptibility of U.S. estuaries to pollution. Rev Aquat Sci 1(2):189-207

Correll DL, Jordan TE, Weller DE (1992) Nutrient fluxing landscape: effects of coastal land-use and terrestrial community mosaic on nutrient transport to coastal water. Estuaries 15: 431-442

Crosby MP, Gale LD (1990) A review and evaluation of bivalve condition index methodologies with a suggested standard method. J Shellfish Res 9(1):233-237

D'Avanzo C, Kremer J (1994) Diel oxygen dynamics and anoxic events in an eutrophic estuary of Waquoit Bay, Mass. Estuaries 17:131-139

Evgenidou A, Valiela I (2002) Response of growth and density of a population of Geukensia demissa to land-derived nitrogen loading, in Waquoit Bay, Massachusetts. Estuar Coast Shelf Sci 55:125-138

Franz DR (1993) Allometry of shell and body weight in relation to shore level in the intertidal bivalve Geukensia demissa (Bivalvia: Mytilidae). J Exp Mar Biol Ecol 174: 193-207

Franz DR (1997) Resource allocation in the intertidal saltmarsh mussel Geukensia demissa in relation to shore level. Estuaries 20:134-148

Jordan TE, Valiela I (1982) A nitrogen budget of the ribbed mussel, Geukensia demissa, and its significance in nitrogen flow in a New England salt marsh. Limnol Oceanogr 27:75-90

Kreeger DA, Newell RIE (1996) Ingestion and assimilation of carbon from cellulolytic bacteria and heterotrophic flagellates by mussels Geukensia demissa and Mytilus edulis (Bivalvia, Mollusca). Microb Ecol 11:205-214

Kreeger DA, Newell RIE (2000) Trophic complexity between producers and invertebrate consumers in salt marshes. In: Weinstein MP, Kreeger DA (eds) Concepts and controversies in tidal marsh ecology. Kluwer Academic Publishers, Dordrecht, p 187-220

Kreeger DA, Newell RIE, Langdon CJ (1990) Effect of tidal exposure on utilization of dietary lignocellulose by the ribbed mussel Geukensia demissa (Dillwyn) (Mollusca:Bivalvia). J Exp Mar Biol Ecol 144:85-100

McClelland JW, Valiela I (1998) Linking nitrogen in estuarine producers to land-derived sources. Limnol Oceanogr 43: 577-585

McClelland JW, Valiela I, Michener RH (1997) Nitrogen stable isotope signature in estuarine food webs: a record of increasing urbanization in coastal watersheds. Limnol Oceanogr 42:930-937

McKinney RA, Nelson WG, Charpentier MA, Wigand C (2001) Ribbed mussel nitrogen isotope signatures reflect nitrogen sources in coastal salt marshes. Ecol Appl 11: 203-214

Nielsen KJ, Franz DR (1995) The influence of adult conspecifics and shore level on recruitment of the ribbed mussel Geukensia demissa (Dillwyn). J Exp Mar Biol Ecol 188:89-98

Packard GC, Boardman TJ (1988) The misuse of ratios, indices, and percentages in ecophysiological research. Physiol Zool 61(1):1-9 
Peterson BJ, Howarth RW, Garritt RH (1986) Sulfur and carbon isotopes as tracers of salt-marsh organic matter flow. Ecology 67:865-874

Scott GI, Lawrence DR (1982) The American oyster as a coastal zone pollution monitor: a pilot study. Estuaries 5(1):40-46

Steel RGD, Torrie JH, Dickie DA (1997) Principles and procedures of statistics, 3rd edn. McGraw Hill, New York

Thursby GB, Abdelrhman M (2004) Growth of the marsh elder Iva frutescens in relation to duration of tidal flooding. Estuaries 27:217--24

Valiela I, Foreman K, LaMontagne M, Hersh D and 8 others (1992) Couplings of watersheds and coastal waters: sources and consequences of nutrient enrichment in Waquoit Bay, Massachusetts. Estuaries 15:443-457

Valiela I, Collins G, Kremer J, Lajtha K, Geist M, Seely B, Brawley J, Sham CH (1997) Nitrogen loading from coastal watersheds to receiving estuaries: new method and application. Ecol Appl 7:358-380

Editorial responsibility: Lisa A. Levin (Contributing Editor), La Jolla, California, USA
Valiela I, Cole ML, McClelland J, Hauxwell J, Cebrian J, Joye SB (2000) Role of salt marshes as part of coastal landscapes. In: Weinstein MP, Kreeger DA (eds) Concepts and controversies in tidal marsh ecology. Kluwer Academic Publishers, Dordrecht, p 23-38

Warwick RM, Platt HM, Clarke KR, Agard J, Gobin J (1990) Analysis of macrobenthic and meiobenthic community structure in relation to pollution and disturbance in Hamilton Harbour, Bermuda. J Exp Mar Biol Ecol 138:119-142

Wigand C, Comeleo R, McKinney R, Thursby G, Chintala M, Charpentier M (2001) Outline of a new approach to evaluate ecological integrity of salt marshes. Human \& Ecol Risk Assess 7(5):1541-1554

Wigand C, McKinney R, Charpentier M, Chintala M, Thursby G (2003) Relationships of nitrogen loadings, residential development, and physical characteristics with plant structure in New England fringe salt marshes. Estuaries 26(6):1494-1504

Submitted: August 1, 2004; Accepted: February 2, 2006 Proofs received from author(s): August 4, 2006 